\title{
Relationship Study between the Alkaline Protease Production and the Growth Phases of Pseudomonas aeruginosa Isolated from Patients
}

\author{
Ali Jaffar Saleem \\ College of Education for Pure Science, Diyala University, Baquba, Iraq \\ Email: alijaffar3@yahoo.com
}

Received July 2, 2012; revised July 31, 2012; accepted August 9, 2012

\begin{abstract}
This study was conducted in Diyala University Laboratories collaboration with the Directorate of Diyala Health. Occurrence of Pseudomonas aeruginosa was investigated in 161 samples from different clinical sources included Swabs from wounds, burns, ear, eye and samples from Urine and sputum which were collected from patients. Depending on the cultural and micro features and biochemical tests 49 isolated items of this bacteria have been diagnosed and all the isolates showed the proteolytic activity by using skim milk agar through forming clear zone around the growing colonies, and tested the isolates ability of alkaline protease production by quantitative methods, the local isolation $P$. aeruginosa AP3 had been selected based on the higher productivity of enzyme comparing to other isolates and thus it was used in the current study. Studied the relationship between the production of alkaline protease enzymes and growth phases of $P$. aeruginosa to determine the time of the enzyme production and the results showed that the local isolation $P$. aeruginosa AP3 began production of the enzyme in the later stages of the log phase and increased production significantly in the stationary phase reaching amaximum after 48 hours as estimated the enzyme activity 159.2 units/ml in the farm leaky and keep the enzyme fully functional almost in the stationary phase.
\end{abstract}

Keywords: Alkaline Protease; Pseudomonas aeruginosa; Growth Phases; Production

\section{Introduction}

Pseudomonas aeruginosa is the most important types of gram-negative pathogenic bacteria to the human, as characterized by their ability to make different types of infection intensity ranging between lethal and moderate. This bacteria is an opportunistic pathogens as they cause serious infections, especially among cancer patients and Immunocompromised patients, and also cause these bacteria infections in different sites of the body they cause respiratory tract infection, cystic fibrosis, pneumonia, urinary tract infection, middle ear infection (Otitis Media), infection of the eye especially bacterial Keratitis, endocarditis, meningitis, bacteremia, septicemia, of bones and joints infection, intestinal infections and skin, burns and wounds infection especially wounds after operations [1].

These bacteria cause infections in burn wounds, causing serious infections in the skin and tissues and may lead to get septicemia, where the burn wounds, a good nutrient medium for microorganisms and through it is colonization and entry into the body and events a series of infections [2].
The ability of $P$. aeruginosa in the invasion of tissues to produce extracellular enzymes and toxins, include exotoxin-A, hemolysin, exoenzyme-S, urease, elastase and alkaline protease because they penetrate the body barriers and damage the host cells and the alkaline protease which plays an important role in the enabling it to invade tissues and settled down to comprehensive infection through the provision of basic food factors for growth [3], It also serves to provide protection for them through the inhibition of some components of the immune system of the host, alkaline protease acting to prevent the opsonization by antibodies and complement, also inhibits neutrophil chemotaxis, also works to reduce the production of gamma interferon, causing reduced antiviral activity [4].

Have this enzyme the ability to destroy synthetic proteins such as collagen and glycoprotein in the tissues [5]. The secretion of this enzyme outside the bacterial cell-by one step directly from the internal membrane to the external membrane while going through another extracellular proteins secreting by two steps [6].

Proteases are the most important industrial enzymes that execute a wide variety of functions and have various 
important biotechnological applications [7]. Microorganisms are the most important sources for enzyme production which is a big economic return through growth on the sources of carbon and nitrogen low-cost [8].

Alkaline proteases of microbial origin possess considerable industrial potential due to their biochemical diversity and wide applications in tannery and food industries, medicinal formulations, detergents and processes like waste treatment, silver recovery and resolution of amino acid mixtures $[9,10]$.

Due to the importance this enzyme and its role in the pathogenesis of $P$. aeruginosa as well as the importance of proteases generally in the fields of pharmaceutical, medical and industrial, this study was to demonstrate the relationship the alkaline protease production with growth phases of local isolation selected of P. aeruginosa.

\section{Material and Methods}

Occurrence of $P$. aeruginosa was investigated in 161 samples from different clinical sources included Swabs from wounds, burns, ear, eye and samples from Urine and sputum. Which were collected from patients in Ba'quba general hospital and Al-Batul hospital for the period from 1/12/2004 until 3/31/2005 and included samples of different ages and both sexes.

Swabs and samples were grown on nutrient agar and blood agar, incubated aerobic conditions at $37^{\circ} \mathrm{C}$ for 24 48 hours to investigate $P$. aeruginosa isolates, and then conducted diagnostic tests of the isolates according to the method described by $[11,12]$. Investigating $P$. aeruginosa ability of Proteolytic Activity by using skim milk agar [13].

Investigate bacterial ability to produce alkaline protease by using casein broth described by Al-Shehri and Mostafa [14], have been adopted optimal conditions of local isolation selected in the alkaline protease production which have been identified by Saleem [15], by using liquid cultures consisting of $0.75 \%$ glucose, $1 \%$ Tripton, $0.1 \% \mathrm{CaCl}_{2}, 0.01 \% \mathrm{MgSO}_{4} \cdot 7 \mathrm{H}_{2} \mathrm{O}, 1.7 \% \mathrm{~K}_{2} \mathrm{HPO}_{4}$ and $0.3 \% \mathrm{KH}_{2} \mathrm{PO}_{4}$ at primary pH of 8 and $37^{\circ} \mathrm{C}$.

$50 \mathrm{ml}$ of medium was taken in a $250 \mathrm{ml}$ conical flask, the flasks were sterilized in autoclave at $121^{\circ} \mathrm{C}(15 \mathrm{lb})$ for $15 \mathrm{~min}$ and after cooling, the flask was inoculated with $1 \times 107 \mathrm{cell} / \mathrm{ml}$. The inoculated flasks were incubated in a shaker incubator at $150 \mathrm{RPM}$ at $37^{\circ} \mathrm{C}$, at the end of the fermentation period, the culture medium was centrifuged at $5000 \mathrm{RPM}$ at $4^{\circ} \mathrm{C}$ for $15 \mathrm{~min}$ to obtain the crude extract, which served as enzyme source. Then alkaline protease was determined by the method of McDonald and Chen, described by [16].

\section{Results and Discussion}

Depending on the cultural and micro features and bio- chemical tests 49 isolated items of $P$. aeruginosa have been diagnosed, all the isolates showed the ability to proteolytic activity by using skim milk agar through forming clear zone around the growing colonies.

The local isolation $P$. aeruginosa AP3 shown in Figure 1, isolated of burns was selected, because it is the heaviest of the enzyme production compared with the other isolates by using the submerged farms and adopted in the current study.

Follow-up has been the growth curve of local isolation $P$. aeruginosa AP3 for 60 hours to know the growth phases and the start time of alkaline protease production during this period by counting the living cells and measuring the absorbance at $600 \mathrm{NM}$ wavelength.

Identified the results shown in Figure 2, which shows the relationship between production and growth phases estimated by counting the living cells and the Figure 3, which shows the same relationship estimated by absorption at wavelength $600 \mathrm{NM}$, the local isolation selected interference in the stationary phase after 10 hours, also was noted the start of alkaline protease production in the leaky farm after 8 hours of the vaccination, the enzyme activity was reaching 6.4 units/ml and continued to gradually increase until it reached a maximum after 48 hours, amounting to 159.2 unit/ml, was also noted the local isolation $P$. aeruginosa AP3 intervention Decline phase after this time, but the enzymatic activity remains relatively high levels was reaching 133.4 unit/ml after 54 hours.

This study shows that the expression of alkaline protease production start in Logarithmic Phase, and increased significantly in the later stages of the Log phase and in Stationary phase. Noticeable the stationary phase elongation of the main points to increase this enzyme production.

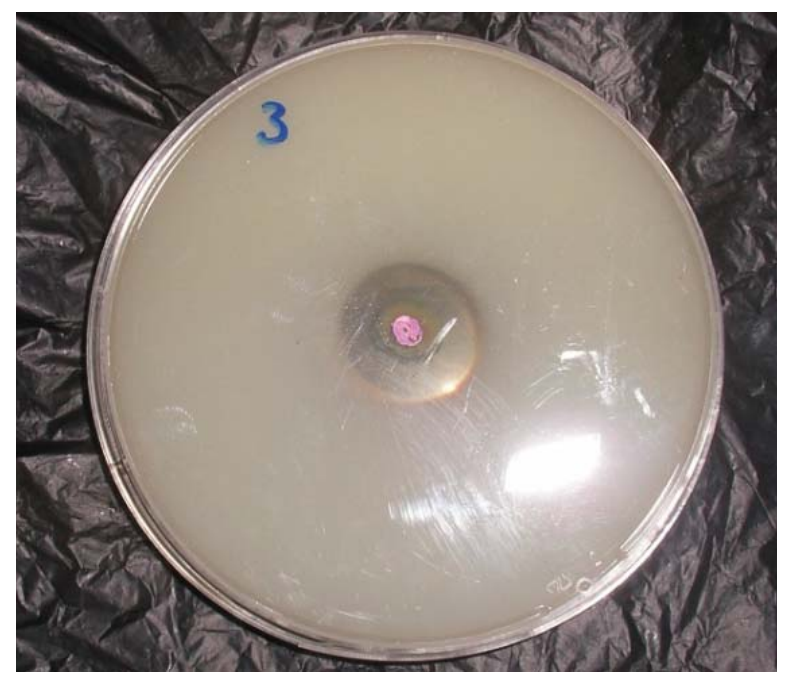

Figure 1. Proteolytic activity of local isolation $P$. aeruginosa AP3 in skim milk agar. 


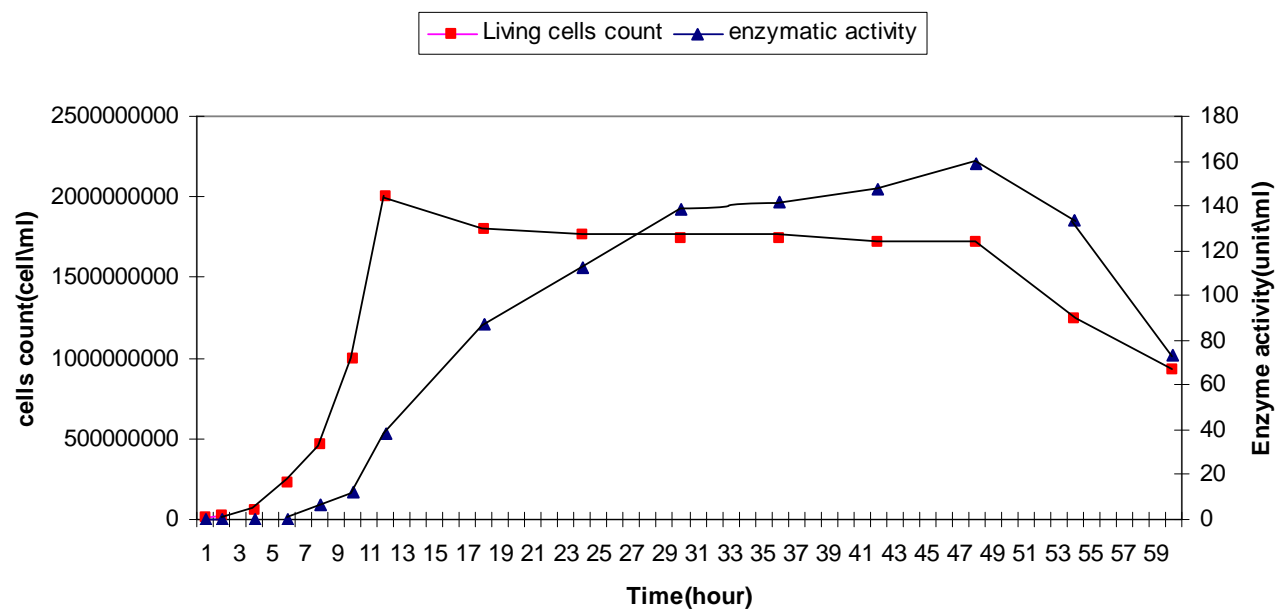

Figure 2. Development of alkaline protease production during growth phases local isolation P. aeruginosa AP3 according to total bacteria count.

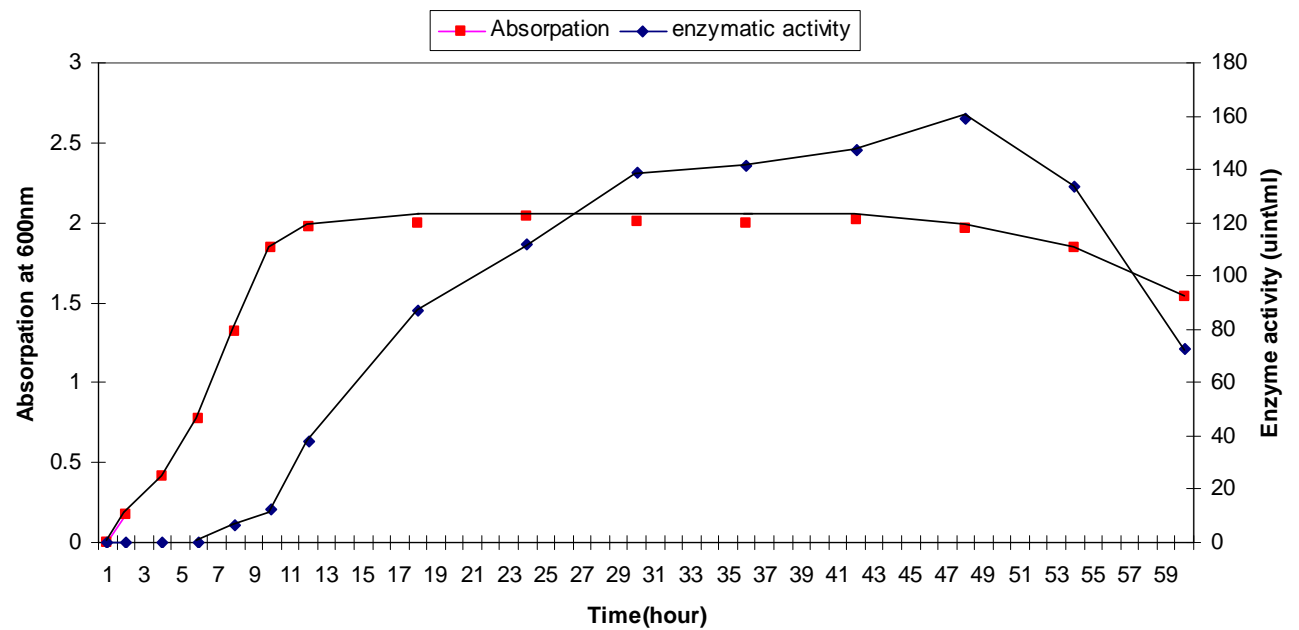

Figure 3. Development of alkaline protease production during growth phases local isolation P. aeruginosa AP3 according to absorption.

Indicated many of the scientific literature that the production of protease happens at the end of Log phase and the beginning of Stationary phase, as noted Oreilly and Day the protease production is happening in the end Log phase and the beginning of Stationary phase and keep the enzyme active in the Enzyme production medium for a period of not less than 12 hours of the entry Stationary phase [17], and this was confirmed by several studies that the extracellular enzymes produced in the beginning of Stationary phase [18]. In another study noted Horsburhg et al., the genes cloned which responsible for the protease production mainly occur in the period post-Log phase [19], and gene las R control to stimulate the production of virulence factors through its role in the process of elastase gene las B cloning and protease gene las A and Tox A [20].

In the local studies indicated Al-Tai that the highest specific activity of the protease product from Aeromonas hydrophila occurred at the end of Log phase and the beginning of Stationary phase [21], and Indicated Saud that the protease produced from Staphylococcus aureus begins at the end of Log phase and during Stationary phase [22].

\section{REFERENCES}

[1] M. Pollack, "Principles and Practice of Infectious Diseases," 5th Edition, Churchill Livingstone, New York, 2000.

[2] J. A. Sleigh and M. C. Timbury, "Notes on Medical Bacteriology," 5th Edition, Churchill Livingstone, Singapore, 1998.

[3] K. A. Kernacki, J. A. Hobden, L. D. Hazlett, R. Fridman and R. S. Berk, "In Vivo Bacterial Protease Production during Pseudomonas aeruginosa Corneal Infection," Investigative Ophthalmology \& Visual Science, Vol. 36, No. 7, 1995, pp. 1371-1378. 
[4] C. Van Delden, E. C. Pesci, J. P. Pearson and B. H. Iglewski, "Starvation Selection Restores Elastase and Rhamnolipid Production in a Pseudomonas aeruginosa Quorum-Sensing Mutant,” Infection and Immunity, Vol. 66, No. 9, 1998, pp. 4478-4502.

[5] K. Sakata, H. Yajima, K. Tanka, Y. Sakamoto, K. Yamamoto, A. Yoshida and Y. Dohi, "Erythromycin Inhibits the Production of Elastase by Pseudomonas aeruginosa with Affecting Its Proliferation in Vitro," The American Review of Respiratory Disease, Vol. 148, No. 1, 1993, pp. 1061-1065. doi:10.1164/ajrccm/148.4_Pt_1.1061

[6] J. L. Kadurugamuwa and T. J. Beveridge, "Virulence Factors Released from $P$. aeruginosa in Associated with Member Vesicles during Normal Growth and Exposure Gentamicin Novel Mechanism of Enzyme Secretion,” Journal of Bacteriology, Vol. 177, No. 14, 1995, pp. 39984008.

[7] F. N. Mohen, D. Dileep and D. Deepthi, "Potential Application of Protease Isolated from Pseudomon aeruginosa PD100,” Electronic Journal of Biotechnology, Vol. 8, No. 2, 2005, pp. 197-203.

[8] K. Kalaiarasi and P. U. Sunitha, "Optimization of Alkaline Protease Production from Pseudomonas fluorescens Isolated from Meat Waste Contaminated Soil," African Journal of Biotechnology, Vol. 8, No. 24, 2009, pp. 70357041.

[9] R. Gupta, Q. K. Beg and P. Lorenz, "Bacterial Alkaline Proteases: Molecular Approaches and Industrial Application,” Applied Microbiology and Biotechnology, Vol. 59, No. 1, 2002, pp. 15-32. doi:10.1007/s00253-002-0975-y

[10] D. Agarwal, P. Patidar, T. Banerjee and S. Patil, "Production of Alkaline Protease by Penicillium sp. under SSF Conditions and Its Application to Soy Protein Hydrolysis,” Process Biochemistry, Vol. 39, No. 8, 2004, pp. 977981. doi:10.1016/S0032-9592(03)00212-7

[11] J. G. Collee, B. P. Marmion, A. G. Fraser and A. Simmons, "Mackie and McCartne Practical Medical Microbiology,” 40th Edition, Churchill Livingstone, New York, 1996.

[12] J. G. Holt, N. R. Kreig, P. H. A. Sheath, T. T. Staley and S. T. Williams, "Bergey's Manual of Determinative Bacteriology," 9th Edition, Williams and Wilkns, Philadelphia, 1994.
[13] R. Cruickshank, J. P. Duguid, B. P. Marmion and R. H. A. Swain, "Medical Microbiology," 12th Edition, Vol. 2. Churchill Livingstone, London, 1975.

[14] M. A. Al-Shhri and S. Y. Mostafa, "Production and Some Properties of Protease Produced by Bacillus Licheniformis Isolated from Tihamet Aseer, Saudi Arabia," International Journal of Biological Sciences, Vol. 7, No. 9, 2004, pp. 1631-1635.

[15] A. J. Saleem, "Biochemical Study of Alkaline Protease Produced from Pseudomonas aeruginosa Isolated from Patients,” M.Sc. Thesis, College of Education for Pure Science, University of Diyala, Baquba, 2007.

[16] Ikram-ul-Haq, H. Mukhtar, Z. Ali and N. Riaz, "Protease Biosynthesis by Mutant Strain of Penicillium griseoroseum and Cheese Formation," International Journal of Biological Sciences, Vol. 7, No. 9, 2004, pp. 1473-1476.

[17] T. Oreilly and D. F. Day, "Effect of Cultural conditions on Protease Production by Aeromonas hydrophilia," Applied and Environmental Microbiology, Vol. 45, No. 3, 1983, pp. 1132-1135.

[18] A. L. Cheung, K. J. Eberhardt, E. Chung, et al., "Diminished Virulence of sar-/agr-mutant of Staphylococcus aureus in the Rabbit Model of Endocarditis," Journal of Clinical Investigation, Vol. 94, No. 5, 1994, pp. 18151822. doi:10.1172/JCI117530

[19] M. J. Horsburgh, J. L. Aish and I. J. White, "Sigma B Modulates Virulence Determinant Expression and Stress Resistance: Characterization of a Functional rsb V Strain Derived from Staphylococcus aureus 8325-4," Journal of Bacteriology, Vol. 184, No. 19, 2002, pp. 5457-5467. doi:10.1128/JB.184.19.5457-5467.2002

[20] M. J. Gambello, S. Kaye and B. H. Laglewski, "Las R of $P$. aeruginosa Is a Transcriptional Activators of the Alkaline Protease Gene (apr) and an Enhancer of Exotoxin-A Expression,” Infection and Immunity, Vol. 61, No. 4, 1993, pp. 1180-1184.

[21] N. M. I. Al-Tai, "Biochemical Study of Protease Enzymes Produce from the Locally Isolated Aeromonas hydrophila," Ph.D. Thesis, College of Science, University of Baghdad, 2005.

[22] A. M. Saud, "Biochemical Study of Protease Enzymes Produce from Staphylococcus aureus Isolated Locally,” M.Sc. Thesis, College of Science, 2005. 